\title{
はちみつによる食中毒の病因物質について
}

(平成 5 年 6 月 25 日受理)

\begin{tabular}{|c|c|}
\hline 最 所 和 宏*1 & 豊田 正 武*1 \\
\hline 佐 竹 元 吉*1 & 高 橋＼cjkstart悟*2 \\
\hline 葛 西＼cjkstart健*3 & 橋 本 勢 津*3 \\
\hline
\end{tabular}

\section{Identification of Aconitine in Raw Honey that Caused Food Poisoning}

\author{
Kazuhiro SaISHo*1, Masatake Toyoda ${ }^{* 1}$, Kayoko TAKAGI ${ }^{* 1}$, Motoyosi Satake*1, \\ Satoru TaKahashi*2, Yasuaki Yamamoto*2, Ken Kasai*3, \\ Setu Hashimoto ${ }^{* 3}$ and Yukio SaIto ${ }^{* 1}$
}

(*1 National Institute of Health Sciences: 1-18-1, Kamiyoga, Setagaya-ku, Tokyo 158, Japan;

${ }^{* 2}$ Iwate Prefectural Institute of Public Health: 15-25, Uchimaru, Morioka, Iwate 020, Japan; *3 Iwate Prefectural Iwaizumi Health Center: 24-3, Matuhashi, Iwaizumi, Iwaizumi-cho, Shimohei-gun, Iwate 027, Japan)

Food poisoning was caused by raw honey in Iwate prefecture on April 15, 1992. To investigate the poisonous substances, the pollens contained in the honey were inspected through a microscope. Most of the pollens (68.3\%) belonged to Aconitum. The honey induced neurotoxic symptoms in rats.

On a thin layer chromatogram of an extract of the honey, a substance having the same $R f$ value as that of aconitine standard was detected. The presence of aconitine in the extract of the honey was confirmed by GC/MS.

Quantification was carried out by high performance liquid chromatography using a modified method for quick extraction and purification of aconitum alkaloids in herb medicines, and the aconitine level in the honey was determined. The concentration was $9.8 \mathrm{ppm}$, which was similar to the estimated level obtained from a toxicity test using killifish.

These results showed that the food poisoning was caused by aconitine in the honey.

(Received June 25, 1993)

Key words： はちみつ honey；食中毒 food poisoning；アコニチン aconitine；高速液体クロマト グラフィー high performance liquid chromatography (HPLC); 薄層クロマトグラフィー thin layer chromatography；神経毒症状 neurotoxic symptom

緒言

平成 4 年 4 月 15 日, 岩手県岩泉町山林において, 林 業従事者が作業中, 倒木の中にハチの巣を発見し，その はちみつを契食した 6 人中 5 人が，喫食後 10 分〜 1 時 間位で, 吐き気, おう吐, 悪寒, 関節のしびれ, 歩行困 難などの食中毒症状を呈し，3名が入院した。 その内の 1 名は意識昏睡状態に陥ったが, 全員治療を受けて回復

*1 国立衛生試験所： 7158 東京都世田谷区上用賀 1-18-1

*2 岩手県衛生研究所： T020 岩手県盛岡市内丸 15-25

*3 岩手県岩泉保健所： $=027-05$ 岩手県下閉伊郡岩泉町岩泉 字松橋 24-3
した.

東北地方では 8 月以降冬までのはちみつは, しばしば 植物由来の有毒成分を含有する危険性があり，喫食を避 ける習慣がある1).しかし，近年はこの習慣を知らない人 む多くなり，また今回の事例のように春先のはちみつで 中毒を起こす事故も起こり, 今後も起こり得る問題なの で，この食中毒の病因物質を探るために，中毒はちみつ 中の花粉の鏡検 ${ }^{2}$, アルカロイドの理化学試験, ラット・ ヒメダカによる毒性試験を行い，二，三の知見を得たの で報告する. 


\section{実験方法}

1. 試料

分析試料：食中毒を起こしたはちみつと同一の場所 より採取したはちみつを遠沈 (3,200 rpm, 20 分間) 後, 上清をとりガーゼによりろ過したもの.

\section{2. 試薬及び装置器具}

\section{1 試薬}

アコニチン標準品（純度約 95\%）及びビス（トリメチ ルシリル）トリフルオロアセトアミド (BSTFA) は Sigma 社製, Sep-pak カートリッシ $\mathrm{C}_{18}$ は Waters 社 製，アセトニトリル，メタノール，テトラヒドロフラン は和光純薬工業(株)製液体クロマトグラフ用，その他の 試薬は試薬特級を用いた。

薄層クロマトグラフィー (TLC) プレート：HPTLC Kiesel gel 60 Art $1374810 \times 10 \mathrm{~cm}$ (Merck 社製)

展開溶媒：25\% アンモ二ア水飽和エーテル

発色試薬：ドラーゲンドルフ試薬（Munier 変法によ

り調製した）

市販はちみつ：東京都内で購入したもの

\section{2 装置, 器具}

高速液体クロマトグラフィー (HPLC) 装置：UV 多波

長検出器付 HP1090 型 (Heulett Packard 社製)

(HPLC 条件)

検出波長：210 $600 \mathrm{~nm}($ モニター $240 \mathrm{~nm}$ )

カラム: Inertsil ODS-2 $4 \mathrm{~mm}$ i.d. $\times 250 \mathrm{~mm}$ (ジーエ ルサイエンス(株)製)

注入量: $20 \mu \mathrm{l}$

移動相：水-テトラヒドロフランーアセトニトリルーク

エン酸 $(85: 15: 5: 1)$

流速: $0.7 \mathrm{ml} / \mathrm{min}$

GC/MS 装置: GC 部, HP5890 (Heulett Packard 社 製)；MS 部，VG70SE (VG Elementary 社製)

(GC/MS 条件)

注入口温度：290

カラム槽温度：初期温度 $200^{\circ}$ (保持時間 2 分) 最終温 度 $320^{\circ}$ (保持時間 15 分) 昇温速度 $15^{\circ} / \mathrm{min}$

キャリヤーガス: ヘリウム

キャリヤーガス流速： $1 \mathrm{ml} / \mathrm{min}$

注入量： $1 \mu \mathrm{l}$ スプリットレス

カラム: HP-1 $25 \mathrm{~m} \times 0.25 \mathrm{~mm}$ 1.d. (Heulett Packard 社製)

パージ時間： $60 \mathrm{sec}$.

イオン源温度： $240^{\circ}$

イオン化電圧： $80 \mathrm{eV}$

加速電圧: $6,000 \mathrm{~V}$

質量数：200 1,000

掃引速度： $1.0 \mathrm{sec}$.

\section{3. 花粉の形龍試験}

分析試料を直接スライドグラスに取り，グリセリン水
及び抱水クロラール試液を用いてマウントした。染色は カルベラ液にて行った。このプレパラートを光学顕微鏡 を用いて, 花粉粒の大きさ, 形, 表面の模様, 花粉管口 の形と数を観察した. レンズは対物レンズ $(\times 20, \times 40$, $\times 100)$ ，接眼レンズ $(\times 20)$ を用いた.

\section{4. 毒性 試 験}

マウス DDY 系雄（体重 $20 \mathrm{~g}$ ）2 匹に分析試料 $0.5 \mathrm{ml}$ を経口投与又は腹腔内投与後症状を観察した。

容量 $100 \mathrm{ml}$ のビーカーに水 $100 \mathrm{ml}$ を入れ, 分析試 料の濃度が 1 及び $5 \%$, 市販はちみつの濃度が 1 及び $5 \%$ ，アコニチンの濃度が $0.1,1$ 及び $10 \mathrm{ppm}$ の水溶液 となるように個別に加えて, 各々市販のヒメダカ 3 匹ず

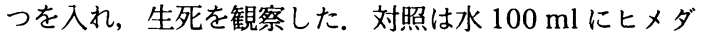
カ3匹を入れたむのとした。

\section{TLC, GC/MS, HPLC 用試験溶液の抽出精製法}

生薬中のアコニチン系アルカロイド迅速抽出精製法に 準じ3), 分析試料 $5 \mathrm{~g}$ をビーカーにとり, $1 \mathrm{~m} M$ 塩酸溶液 $15 \mathrm{ml}$ を加え $50^{\circ}$ に加温して溶解し, 室温にて 5 分間超 音波処理を行った。これを 10 分間 3,500 rpm で遠沈 し，その上清液をとった，沈殿物に対しこの操作を更に 繰り返し，上清液を合わせ, Sep-pak $\mathrm{C}_{18}$ に直接通し, 1 $\mathrm{m} M$ 塩酸溶液 $5 \mathrm{ml}$, 水 $20 \mathrm{ml}, 15 \%$ ×夕ノール水溶液 $5 \mathrm{ml}$ の順に流してカラムを洗い, ついでメタノール 8 $\mathrm{ml}$ でアルカロイド類を溶出させた。. 溶出液 $8 \mathrm{ml}$ を減圧 乾固後, アセトニトリル $200 \mu \mathrm{l}$ に溶解し TLC 及び HPLC 用試験溶液とした。 また, 同じ溶出液 $8 \mathrm{ml}$ を減 圧乾固後, ピリジン $20 \mu \mathrm{l}$ に溶解し BSTFA $20 \mu \mathrm{l}$ を加 え 1 時間 $60^{\circ}$ に加温し TMS エーテル誘導体とし，これ を GC/MS 用試験溶液とした。

\section{結果及び考察}

\section{1. 花粉の形態試験}

はちみつ食中毒患者の症状及び過去の中毒事例 ${ }^{1}$ より アコニチン系アルカロイドによる食中毒であることが考 えられたため, まず花粉の形態試験を行うことにした。

結果を Table 1 に示した. 個々の花粉の形態的な特徵 は以下に記述するとおり，I は紡鍾形・表面平滑，II は 球形・表面平滑, III はやや球形 (上面から見ると三角状 円形）・小刺状紋・3 個の花粉管口がある溝孔粒，IV は

Table 1. Appearance and Incidence of the Pollens Found in the Poisonous Honey

\begin{tabular}{ccc}
\hline \hline & $\begin{array}{c}\text { Size } \\
(\mu \mathrm{m})\end{array}$ & $\begin{array}{c}\text { Detection } \\
(\%)\end{array}$ \\
\hline I & $5 \sim 10 \times 20 \sim 25$ & 7.9 \\
II & $15 \sim 20 \times 15 \sim 20$ & 11.6 \\
III & $15 \sim 20 \times 40 \sim 50$ & 11.6 \\
IV & $20 \sim 22 \times 25 \sim 30$ & 68.3 \\
V & $100 \sim 150 \times 100 \sim 150$ & 0.6 \\
\hline
\end{tabular}


紡錘形・表面やや滑らか・6 個の花粉管口がある溝孔 粒, V は球形.これらの内, IV の花粉は, Aconitum 属 植物の花粉の形態とよく一致し, 出現率が $68.3 \%$ であ ることから，アコニチン系アルカロイドが中毒病因物質 の可能性が高まった.

\section{2. 毒性試験}

分析試料をマウスに $0.5 \mathrm{ml}$ 経口投与すると, 65 分後 に死亡し, けいれん・腰が抜ける・飛び上がるなどの症 状を示した. $0.5 \mathrm{ml}$ 腹腔内投与すると, 5 分後に死亡し, 経口投与の場合と同様な症状を示したほか, 死亡の直前 に眼球が突出した，マウスの毒性試験から，はちみつ試 料中には神経毒が含まれると考えられた。

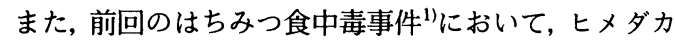
を毒性試験に用いているので, 前回と比較する目的で, 同様な毒性試験を行った. 同時に, 中毒病因物質として アコニチン系アルカロイドの存在が推測されたので, ア コニチン標準品についても並行して行った. 結果は,

Table 2. Acute Toxicity with Killifish (Oryzias latipes)

\begin{tabular}{lccc}
\hline \multirow{2}{*}{ Sample } & \multicolumn{3}{c}{$\begin{array}{c}\text { Number of alive killifish } \\
\text { after exposing to each } \\
\text { test solution* }\end{array}$} \\
\cline { 2 - 4 } & $\begin{array}{l}2^{* *} \\
(\mathrm{hr})\end{array}$ & $\begin{array}{c}4^{* *} \\
(\mathrm{hr})\end{array}$ & $\begin{array}{c}6^{* *} \\
(\mathrm{hr})\end{array}$ \\
\hline Control & 3 & 3 & 3 \\
Aconitine 10 ppm & 0 & 0 & 0 \\
Aconitine 1 ppm & 2 & 2 & 2 \\
Aconitine 0.1 ppm & 2 & 2 & 2 \\
Sample 5\% & 1 & 0 & 0 \\
Sample 1\% & 3 & 3 & 3 \\
Commercial honey 5\% & 3 & 3 & 3 \\
Commercial honey 1\% & 3 & 3 & 3 \\
\hline
\end{tabular}

* Toxicity test was carried out using killifish $(n=3)$ in $100 \mathrm{ml}$ of water containing each test sample above.

** Survival time

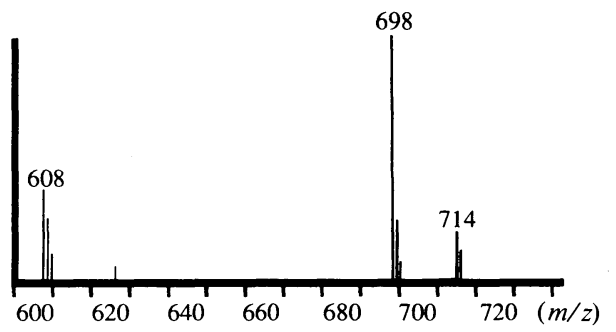

(A)
Table 2 に示すように市販のはちみつでは $5 \%$ 濃度であ ヒメダカは正常であるが, 分析試料では $5 \%$ 濃度で 4 時 間後に 3 匹とも死亡した。一方，アコニチン標準品で は， $1 \mathrm{ppm}$ 以下の低濃度ではいずれも 1 匹のみ死亡し， $10 \mathrm{ppm}$ では 2 時間後で 3 匹とも死亡した.

ヒメダカによる毒性試験の結果からはちみつ試料中 に, アコニチンが存在すると仮定すると, その濃度は 10 〜100 ppm と推定された.

\section{TLCによる定性試験}

分析試料の TLC 用試験溶液について, $40 \mu 1$ をスポッ トし, 展開溶媒として $25 \%$ アンモ二ア水飽和エーテル, 発色試薬としてドラーゲンドルフ試薬を用いTLCを行 ったところ, 分析試料中アコニチン標準品のアセトニト リル溶液と同じ $R f$ 值 0.56 を示すスポットが認められ た. アコニチン標準品 $1,10,100 \mu \mathrm{g}$ との肉眼比較によ り，スポットした TLC 用試験溶液中に $10 \sim 100 \mu \mathrm{g}$ （分 析試料中に 10 100 ppm のアコニチン濃度に相当）の 存在が認められた。

\section{GC/MS による確認試験}

試験溶液中のアコニチンを確認するため，文献)に従 いTMS 誘導体とした後, GC/MSによる解析を行った.

Fig. 1 に示したように分析試料よりアコニチン の bisTMS 体のフラグメントイオンの $m / z 714$ [M$\left.\mathrm{CH}_{3} \mathrm{COO}-\mathrm{CH}_{3}\right]^{+}, \quad 698\left[\mathrm{M}-\mathrm{CH}_{3} \mathrm{COOH}\right]^{+}, \quad 608[\mathrm{M}-$ $\left.\mathrm{CH}_{3} \mathrm{COOH}-\mathrm{OCH}_{3}-\mathrm{TMSOH}\right]^{+}$が観測され, 各ピークの強 度比む標準品と一致し, 分析試料中のアコニチンの存在 が確認された。

\section{HPLCによる定性・定量試験}

本試験で用いた方法, 即ち塩酸酸性抽出後, Sep-pak $\mathrm{C}_{18}$ カートリッジにより精製し HPLC を用いて定量する 方法は，生薬中からアルカロイドを抽出する方法 ${ }^{3}$ に準 拠したものである.

そこで市販はちみつを用いて本法によるアコニチンの 添加回収実験を行ったところ，100 ppm 及び $10 \mathrm{ppm}$ 添加で回収率はそれぞれ $86.4 \%$ 及び $104.1 \%$ とほぼ良 好な結果が得られ，本法ははちみつからのアコニチン系 アルカロイドの抽出精製法として適していることが分か

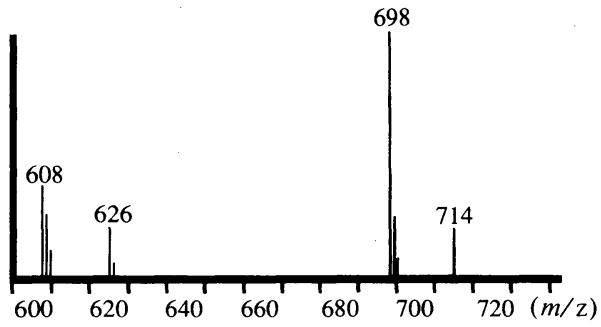

(B)

Fig. 1. Mass spectra of aconitine: (A) authentic aconitine; (B) aconitine from honey 


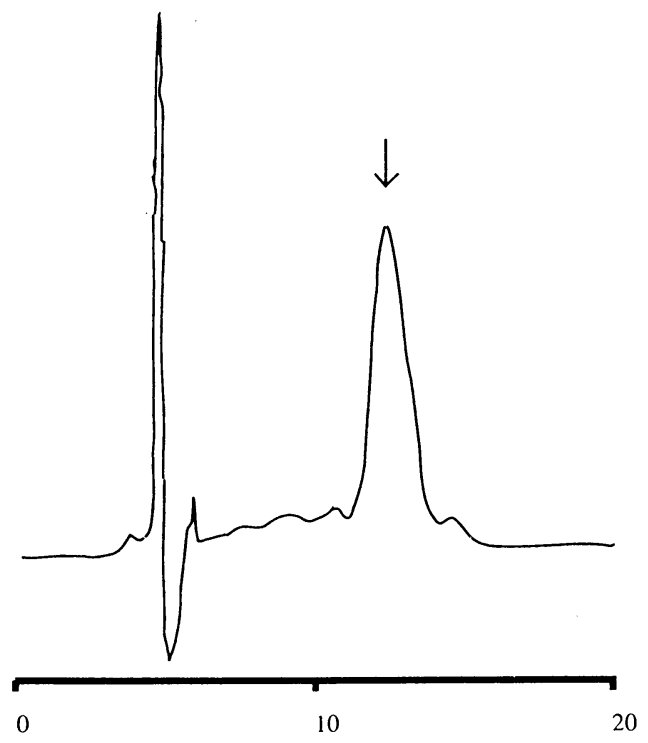

(A)

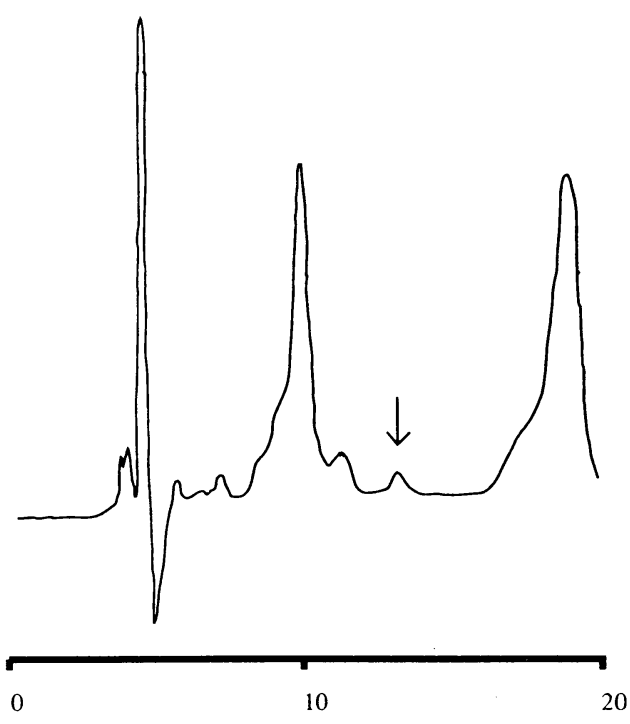

(B)

$\mathrm{R}$ e $\mathrm{t}$ e $\mathrm{n} \mathrm{t}$ i o $\mathrm{n} \mathrm{T}$ i me (m i $\mathrm{n}$ )

Fig. 2. High performance liquid chromatograms of aconitine (A) authentic acontine; (B) aconitine from honey

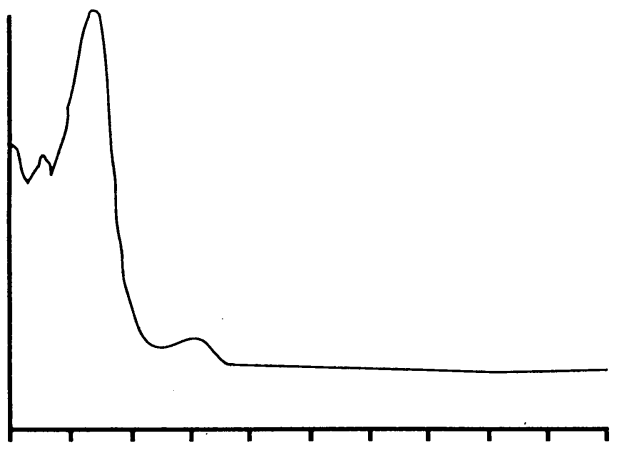

$\begin{array}{lllllllllll}220 & 240 & 260 & 280 & 300 & 320 & 340 & 360 & 380 & 400 & 420\end{array}$

(A)

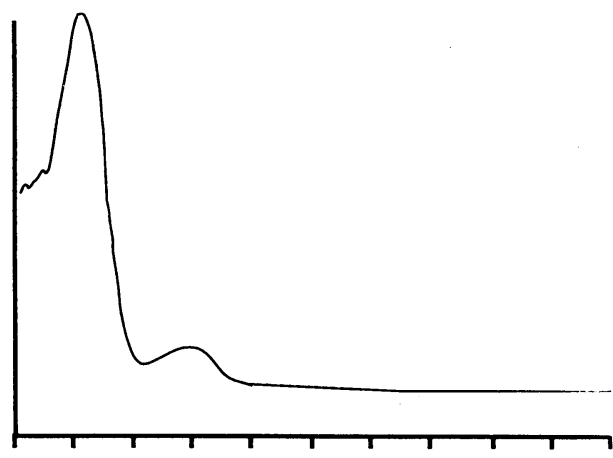

$\begin{array}{lllllllllll}220 & 240 & 260 & 280 & 300 & 320 & 340 & 360 & 380 & 400 & 420\end{array}$

( B )

Wave le $\mathrm{ng} \mathrm{t} h$ ( $\mathrm{nm}$ )

Fig. 3. Absorption spectra of aconitine

(A) authentic aconitine; (B) aconitine from honey

った.

Fig. 2 にアコニチン標準品と分析試料からの抽出液の HPLC によるクロマトグラムを示した. 分析試料にアコ ニチンと保持時間が良く一致するピークの存在が認めら れ, Fig. 3 にそのピークの吸収スペクトルを示した. UV スペクトルは 235 と $275 \mathrm{~nm}$ に極大吸収が見られ，ア コニチンと類似のスペクトルであることが確認された。 HPLC 分析による中毒はちみつ中アコニチン濃度は $10.7 \mathrm{ppm}$ であった.
なお Fig. 2 に見られる保持時間 $9.1 \mathrm{~min}$ の大きなピ 一クの UV スペクトルは, $260 \mathrm{~nm}$ に肩があり, 極大吸 収が $335 \mathrm{~nm}$ と $355 \mathrm{~nm}$ で, これは酸性溶液中における フラボン類のスペクトルに類似していた。 そこで数種フ ラボン類の標品を用い, 同一条件下で HPLC を行い, 各 ピークの吸収スペクトルを測定し比較したところ，フラ ボンのモノ配糖体と保持時間が近く, またスペクトルも

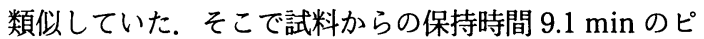
一クを分取し, エーテル, 酶酸エチルの順に振とう抽出 
し，ピーク成分が回収されて来た酢酸エチル画分の UV スペクトルを測定したところ，330 nm (Band I) と 270 nm (Band II) に極大吸収が見られるが，Band I の極大 吸収が $350 \mathrm{~nm}$ 以下である事から，含有成分はフラボ, ールではなくフラボンと推定副された。一方保持時間 $17.0 \mathrm{~min}$ の大きなピークはUV 吸収スペクトルのパ夕 ーンより有機酸類ではないかと推定された。これら HPLCで推定されたアコニチン以外の成分は致死量が はるかに高く（アピゲニンのモノ配糖体の $\mathrm{LD}_{20} 1 \mathrm{mg} /$ $\mathrm{kg}^{6)}$ ，クエン酸の $\mathrm{LD}_{50} 883 \mathrm{mg} / \mathrm{kg}^{7)}$ など)，また中毒症 状も異なることから，食中毒の病因物質とは考えられな かった。

トリカブトを原因とする食中毒が 2 例8) 9 報告されて いる. しかし，これらの場合実際に喫食したトリカブト のアコニチン量は不明であるため, 中毒量の予測は困難 であるが，ヒトでの致死量は $2 \sim 5 \mathrm{mg}^{10)}$ といわれてお り，仮に中毒量を致死量の $1 / 100$ とすると中毒量は 20 $\sim 50 \mu \mathrm{g}$ となる. 今回のはちみつを匙に 1 杯 (小匙 1 さ じは水なら約 $1.8 \mathrm{~g}$ ) 食べたとすると, その摂取アコニチ ン量は約 $20 \mu \mathrm{g}$ に相当し, これは中毒が起こりうる量と 考えられる. 従って, 今回のはちみつ中のアコニチン濃 度 $10.7 \mathrm{ppm}$ は妥当な値と考えられる。

総 括

はちみつ検体中の中毒病因物質を検索した，中毒症状 からアコニチン系アルカロイドが推定されたため, まず 花粉の形態試験を行い, Aconitum 属植物の花粉が 68.3\% と高い出現率であった. 更に, 生薬のアルカロイ ドの抽出精製法に準じアルカロイドを抽出し，TLCに より定性，HPLCにより定量を行ったところ，アコニチ
ンの存在が認められ，その濃度は $10.7 \mathrm{ppm}$ であり，こ れはヒメダカを用いた毒性試験の結果から推定される含 有量範囲に近い值となっていた。また GC/MS 分析によ りアコニチンの存在が確認できた。これらの結果から中 毒病因物質はトリカブト由来のアコニチンであり, 中毒 はちみつ中のアコニチン含量は約 $10 \mathrm{ppm}$ と考えられ た.

\section{謝辞}

本研究に当たり, $\mathrm{GC} / \mathrm{MS}$ 分析にご協力頂きました日 本食品分析センター仲村忠雄氏に深謝致します。

文献

1）斎藤行生, 光楽昭雄, 佐々木久美子, 佐竹元吉, 内山 充: 衛生試報, 98, 32 35 (1980).

2) 佐竹元吉：同上 87, 81 82 (1969).

3) 中野道晴, 山岸 喬: 北海道衛生研究所報, 32, 21 26 (1982).

4）水柿道直, 大山良治, 木村勝彦, 石橋 正, 大野㫿吉, 内 間栄行, 永 盛肇, 鈴木康男：衛生化学 34, 359 365 (1988).

5) Markham, K. R.: "Techniques of Flavonoid Identification" p. 36 51 (1982), Academic Press, New York.

6) Prabhakar, M. C., Bano, H., Kumar, I., Shamsi, M. A., Khan, M. S. Y.: Planta Medica 43, 396 403 (1981).

7) Gruber, C. M. Jr., Halbeisen, W. A.: J. Pharm. Exp. Therapeu. 94, 65 67 (1948).

8) 吉井玄亮：食衛誌. 25, 465 466 (1984)

9）管井博文：同上 32，450４51 (1991).

10）藤原喜久夫，粟飯原景昭編：“食品衛生ハンドブック” p 189 191 (1992), 南江堂. 